\title{
Designing a collaborative business model for ${ }_{26^{N} \text { May } 2014}^{\text {Recived }}$ SMEs

\author{
Angela Caridà - Maria Colurcio - Monia Melia
}

\begin{abstract}
Purpose of the paper: This study aims to contribute to the literature on business model by providing some fresh insights about collaborative business models for SMEs. Specifically, the paper describes and analyzes the business model set up by an Italian start up, Formabilio, which is built up on both network and digital technologies.

Methodology: An explorative, qualitative research design (Burr, 2003; Colurcio et al., 2012) has been employed. Data have been collected through the analysis of documents and texts, non-participant observations, an online semi-structured questionnaire and in-depth interviews.

Findings: The study suggests an holistic and strategic approach to renew the business model. It identifies the foundational elements of a collaboration-based business model to sustain the SMEs competitiveness in a complex and increasingly digital-based ecosystem. Specifically, the analysis of the Formabilio network discloses new possible business configurations that a company can adopt to create value for all the actors engaged in the business ecosystem.

Research limits: The main limitation of the empirical study relates to its explorative nature and the analysis of a single collaborative network.

Practical implications: The study discloses possible business configurations as the pivotal factors for designing value co-creation business models. It offers an opportunity to reflect on the effects of collaboration and networking on a traditional business context as the Italian manufacturing ecosystem.

Originality of the paper: The paper adds value to the existing literature by providing a broader perspective of analysis that merges the managerial perspective on the business model and the marketing perspective of interaction and resources integration, to understand and to guide the managerial behaviour.
\end{abstract}

Key words: collaboration business model; collaborative network; Service Dominant Logic; manufacturing SMEs; Formabilio

\section{Introduction}

During the last decades changes in the competitive environment forced manufacturing firms to adopt new business models increasingly focused on partnering with different actors within complex ecosystems (Myers, 2006). "Competitiveness is no longer between enterprises, but between enterprise networks" (Lee et al., 2010). Furthermore, in the context in which knowledge and competencies become the real source of the competitive advantage, the interaction between many players is more and more critical for firms in 
sinergie Vol. 33, N. 98, 2015

developing dynamic and successful strategies (Russo Spena and Colurcio, 2010).

As some studies have emphasized, (Goss, 1991; Pratten, 1991; Rothwell and Dodgson, 1992; Colurcio et al., 2012) collaboration is a necessary strategy - especially for small and medium size enterprises (SMEs) - both of them to overcome their limitations of resources and to balance the size/power asymmetry (Colurcio, 2009, Johnsen and Ford, 2008). Many authors have highlighted that external partnerships give SMEs the flexibility to open up to new frontiers (market/technological/ relational) and face the fast changing environment as well as to bridge their own resources gaps (Colurcio et al., 2012; Ulaga and Eggert, 2005). The strategy of collaboration is - in some cases - the only way to survive and compete in the market.

The network approach shifts from the focal firm perspective to an open and global perspective that matches and integrates the standpoints of the diverse actors (Rampersad et al., 2010) who contribute to the collective construction of value by integrating resources (Vargo, 2008; Vargo and Lusch, 2008; Colurcio et al., 2014).

Both from the academics' and practitioners' point of view, the new interaction possibilities provided by the web based technologies have renovated and increased the interest in collaboration and networking (Schau et al., 2009; Sawhney et al., 2005; von Hippel 2005). For example, referring to innovation strategy, interactive technologies allow the broad application of techniques and tools to stimulate the participation and the engagement of the entire firm network in the generation, selection and launch of ideas (Caridà and Colurcio, 2013; Schau et al., 2009).

Social interaction through web-based technologies (WBTs) discloses a high potential in sustaining manufacturing companies competitiveness, as it allows SMEs, that traditionally rooted their competitiveness in a mix of economic relationships and social ties (Chiarvesio et al., 2004), to collaborate with customers (Schau et al., 2009; Sawhney et al., 2005; McAlexander et al., 2002), as well as, with the entire firm's network (e.g. experts, suppliers, etc.). Furthermore, WBTs provide new commercial opportunities (electronic market) for SMEs, enabling them to reach customers in new ways and through a multitude of channels (Chiarvesio et al., 2004; Osterwalder, 2004). In other words, the availability of WBTs increases the possible business configurations that companies can adopt (Osterwalder, 2004).

The technological evolution has led to the emergence of collaboration platforms (Camarinha-Matos, 2009) that require the development of new business models able to ensure the technological, strategic and relational alignment of the partners. This is a precondition to enhance collaboration between actors and to create a synergistic value: "through their interactions, partners transfer knowledge and other resources in developing organizational learning; [...] knowledge, skills and other resources are integrated to put together a network of firms possessing a set of competencies capable of offering a value innovation that is an innovative value proposition which enables higher value co-creation" (Mele et al., 2010). 
The intended purpose of our study is to contribute to the business model literature by identifying the foundational elements for the definition of a collaboration-based business model to enhance the SMEs competition in a Angela Caridà Maria Colurcio complex and increasingly digital-based ecosystem.

The route we chose to address the study is to analyze in depth an empirical case - the collaborative network of Formabilio - in order to provide some insights on the topic of business model from a collaborative network perspective.

The paper adds value to the existing literature, as it provides a wider perspective on collaboration business models. It offers the opportunity of some reflections about the advantages of WBTs for collaboration and networking in a traditional business context such as the Italian manufacturing one.

The remainder of this paper is organized as follows. First, we review the literature on business model. Then we present the research design and discuss the results. Finally, we draw the theoretical and managerial implications.

\section{Theorethical backbone}

Since the mid 1990s, interest in business models has grown considerably among scholars and practitioners (Berglund and Sandström, 2013; Zott et al., 2011). The advent of the internet is one of the main reasons of such an interest (Amit and Zott, 2001; Zott et al., 2011), as well as, the global competition, the development of flexible manufacturing technologies, and the industrial and technological convergence (Berglund and Sandström, 2013). However, despite the interest and the literature debate, there is no general consensus regarding the definition (Berglund and Sandström, 2013; Zott et al., 2011), nature, structure, and the evolution of business models (Morris et al., 2005). It is a very fragmented and multidisciplinary concept that includes different elements according to the researchers' field of interest.

As pointed out by Morris et al. (2005) the concept of business model can be defined according to an economic, operational and/or strategic level. From the economic standpoint, the business model focuses on specific variables, such as, revenue sources, pricing methodologies, cost structures, etc. (Afuah and Tucci, 2003). It represents "a statement of how a firm will make money and sustain its profit stream over time" (Stewart and Zhao, 2000). In an operational context, the business model is an architectural configuration (Osterwalder et al., 2005), that is mainly focused on internal processes and on the infrastructure design to create value. It includes a description of the various business actors and their roles, as well as, of different benefits achievable by them (Timmers, 1998).

Finally, in a strategic meaning the concept of business model emphasizes the market positioning of the firm, the networks alliances, the growth opportunities and the competitive advantage and sustainability (Hamel 2000; Chesbrough and Rosenbloom, 2002). In sum, the business model concept has been referred to as a statement, a description, an architecture, a conceptual tool or model, a method, a framework, a pattern, and a set of activities (Morris et al., 2005; Zott et al., 2011). Drawing from this 
Sinergie Vol. 33, N. 98, 2015

conceptual variety, Morris et al. (2005, p. 727) provide the following integrative definition of business model: "it is a concise representation of how an interrelated set of decision variables in the areas of venture strategy, architecture, and economics are addressed to create sustainable competitive advantage in defined markets".

The three meanings of the business model concept, we cited above, can be referred to three main areas of investigation (Berglund and Sandström, 2013; Zott et al., 2011): i) the e-business and the use of information technology in organizations; ii) the strategic issues relating to the distinction between the business model and other strategy concepts, the relationship between business models and firm performance and more recently the networked nature of value creation. This latter area of study focuses mainly on the complex and interconnected set of exchange relationships among multiple players; iii) the issue of innovation and technology management that frames technology as an enabler of the business model rather than as a part of the concept per se.

Due to the lack of consensus on what a business model is and the multidisciplinary research areas that address the topic, both scholars and practitioners call for a more integrated perspective of analysis to keep studies on business models doable and meaningful (Morris et al., 2005; Zott et al., 2011). According to this, and drawing from the shared issues within the literature on business model (Berglund and Sandström, 2013), the business model can be viewed as a set of components and their interrelationships that transcend the boundaries of each single firm to describe how firms create (Amit and Zott, 2001), deliver and appropriate value (Chesbrough and Rosenbloom, 2002; Teece, 2010).

In other words, the business model can be viewed as a new unit of analysis (Stähler, 2002; Zott et al., 2011), as a system-level concept that is centered on activities and focused on value creation as well as on value capture (Zott et al., 2011).

\section{Research design}

\subsection{Aim}

The intended purpose of this study is twofold. First, it aims to contribute to the debate on the business model literature by addressing the call of the scientific community for a perspective which combines the issue related to WBTs, network and value co-creation. Second, it aims to contribute to the managerial debate by identifying the foundational elements of a collaboration-based business model that is able to cope with the challenge of the digital-based ecosystem.

To fulfill our purposes, we focused on the main issues covered by studies on business model to emphasize their interconnection, and to identify the foundational elements for framing a collaboration-based business model.

The study focuses on Formabilio, an Italian company that provides an innovative solution to produce and market original and creative products 
that are in full compliance with the style, quality and tradition of the made in Italy. Formabilio is a network of designers, Italian furnishing SMEs (Partners) and Italian design lovers built up by an Italian furnishing startup Angela Caridà
Maria Colurcio that uses WBTs for three different but linked aims: sourcing and giving shape to the designers' creativity, business networking and e-commerce.

\subsection{Epistemological background}

In order to analyse the business model as a system-level concept (Zott et al., 2011) that is centered on activities and focused on value creation as well as on value capture, we apply a social construction view which is "principally concerned with explicating the process by which people come to describe, explain, or otherwise account for the world (including themselves) in which they live" (Gergen, 1985, p. 266). Social construction understands reality as the context within which the activities of individuals become meaningful (Deighton and Grayson 1995). Accordingly, organizational phenomena can be viewed as socially constructed through a process of interaction among people (Cammock, 1995).

Specifically, Edvardsson et al. (2011) apply some fundamental concepts of social construction theories to the framework of S-D logic. These fundamentals relate social structures and systems, actors' positions and roles, social interactions, and the reproduction of social structures, as a result of a process of ongoing internalization and externalization through interpersonal interactions and "are important in shaping the social reality of actors engaged in exchanging service for service as they jointly co-create value in service systems" (p. 330).

Accordingly, the social construction approach allow us to frame collaboration-based business model as a set of components and interrelationships that transcends the boundaries of firm to describe how it creates, delivers and appropriates value.

\subsection{Research construct}

To analyze and interpret data, we identified foundational elements of a collaboration-based business model considering the main issues on which business model studies have been addressed to: network, value, activities and interactive technologies.

As figure 1 shows, these foundational elements relate to the actors involved within the network, their roles, the different types of value created and their beneficiaries and finally the resources integrated by actors to develop activities and to create value.

Specifically, we define actors as generic entities, who have the capability to integrate resources (Vargo and Lusch, 2008). They are engaged in an exchange relationship and act as resource integrators to carry out activities (Mele et al., 2010). Resources we focus on are mainly operant, such as knowledge, skills, effort, technology etc. (Akaka and Vargo, 2014; Vargo and Lusch, 2008). They act upon other resources to foster new ways of creating value. Activities are the active things that actors carry out through a specific set of interactions (Ballantyne and Varey, 2006) by integrating 
sinergie Vol. 33, N. 98, 2015 resources from multiple sources (McColl-Kennedy et al., 2012). They can be referred to as the Co-s for innovation (Russo Spena and Mele, 2012). However, although it is not specifically emphasised in figure 1 , the interaction - that is enabled by the interactive technologies - and the resource integration process are the main external conditions to address to all the elements of the model toward the value creation. Indeed, value is the potential outcome that actors can extract from the interaction. As Vargo and Lusch (2011, p. 184) stated: "the usefulness of any particular potential resource from one source is moderated by the availability of other potential resources from other sources, the removal of resistances to resource utilization, and the beneficiary's ability to integrate them". Accordingly, value is an abstract concept with specific meanings that vary according to context (Sweeney and Soutar, 2001). It is not limited to the economic or financial aspects but encompasses different interrelated dimensions. The first dimension is social, which is related to the benefits derived through interactions, for example emotional support, selfesteem and social enhancement (Sicilia and Palazon, 2008). The second is emotional, which is related to the utility derived from the affective states (Sheth et al., 1991). Finally, value can be epistemic, which is related to the capacity to arouse curiosity, to provide novelty and/or to satisfy a desire for knowledge (Sheth et al., 1991; Pura, 2005). It includes the concept of learning as the gaining of knowledge (Bourdeau et al., 2002). According to our research construct, the business model can be viewed as the dynamic relational system where all elements are embedded in.

Fig. 1: Toward an integrate business model perspective: main issues and foundational elements

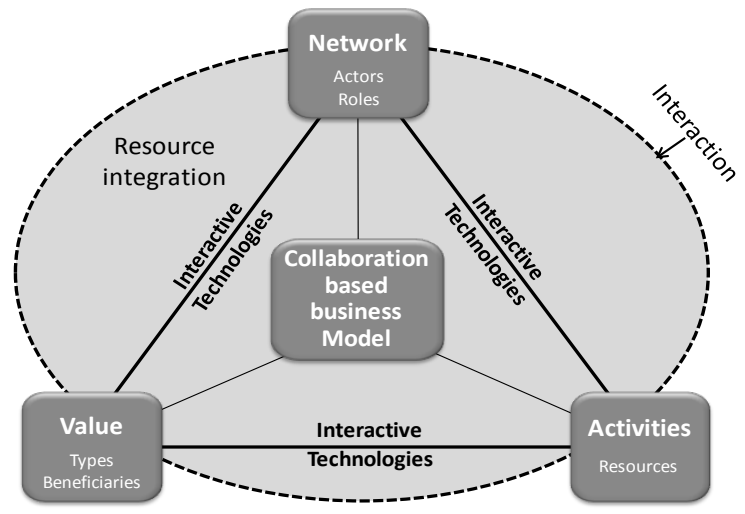

Source: Our elaboration

\subsection{Methodology}

The application of the social construction approach implies an exploratory, qualitative research design (Colurcio et al., 2012; Burr, 2003; Lincoln and Guba, 1985). Table 1 shows the process of data collection and analysis detailing tools, focus, content and time of the research activities. 
Data have been collected through the analysis of documents and texts, non-participant observations, online semi-structured questionnaires and in-depth interviews.

Angela Caridà

Monia Melia

Designing a collaborative

business model for SMEs

First of all, we developed a documentary analysis as it is an useful research method for integrating investigation conducted through direct observation or questioning (Hammersley and Atkinson, 1995). We focused on existing documents as media reports, publicity materials and procedural documents (e.g. contest rules, reward policy, etc.). To interpret the experiences and the dynamics of interaction within the community we observed for ten months (September 2013 - July 2014) the Formabilio digital platform and monitored messages and texts posted by the community members.

Before downloading, posts have been classified consistently with the fundamentals of our research construct into four main categories: actors' roles, activities developed, resources integrated and the value co-created and captured through the relationship. To analyse the point of view of all actors involved in the Formabilio network, data have been collected through both an online semi-structured questionnaire and in-depth interviews.

Both of these tools are particularly appropriate to capture informants' responses in their own words (Finn et al., 2000; Frankfort-Nachmias and Nachmias, 1996) as their well-established use in qualitative research (Creswell, 1998) prove.

The online semi-structured questionnaire addressed designers and brand lovers. We posted the invitation (in behalf of Formabilio) to participate, together with a discount coupon of $10 \%$ off the products' full price, on the Formabilio website in order to encourage the interest and the participation. 150 respondents fulfilled the questionnaire sufficiently. The questionnaire included open questions relating expectations and benefits that designers and brand lovers achieved from the Formabilio network, as well as closed questions concerning their role and degree of involvement within the community. To this end, we asked information about activities developed (e.g. suggesting new ideas, co-learning, commenting, liking and voting ideas, collecting information, buying products) (McColl-Kennedy et al., 2012), resource integrated and provided by the whole community (e.g. creativity, knowledge, competences, time, efforts, relationships).

Finally in-depth problem centered interviews have been conducted according to a narrative, text-based research design. They involved the Formabilio CEO founders and the managers of small craftsmanship companies (e.g. business partners) engaged in the network. One or two people per company have been interviewed using telephone and Skype. Each interview lasted approximately forty minutes.

The interview form has been designed according to an open and dialogical structure for understanding the experience(s) and the stories of the respondents (Witzel, 2000). Open questions reflect the research construct we elaborated. They related to i) the engagement of the company within the innovation network, ii) the content and the evolution of the relationship, iii) the effects of partnerships. Therefore, data and information have been analyzed and interpreted on the basis of our research construct. More specifically, information about the content of the relationship has been interpreted according to the categories of co-design, co-evaluation, 
sinergie Vol. 33, N. 98, 2015

co-development and co-learning (Russo Spena and Mele, 2012). To analyse and interpret the evolution of the relationship, we referred to the theoretical categories of i) dyadic relationship (Anderson et al. 1994) and ii) multi-actor relationship (Vargo, Lusch, 2011). Our aim was to explore how managers of small craftsmanship companies experienced and perceived their relationships with partners within the Formabilio innovation network and how they configured modes of interaction with them. The interviews were tape-recorded and transcribed verbatim.

The research has been carried out between September 2013 and July 2014.

Tab. 1: Data collection and analysis

\begin{tabular}{|c|c|c|c|c|}
\hline \multicolumn{4}{|c|}{ DATA COLLECTION } & \multirow{2}{*}{$\begin{array}{l}\text { DATA ANALYSIS } \\
\text { HOW (coding and analysis ) }\end{array}$} \\
\hline HOW & WHO & WHAT & WHEN & \\
\hline $\begin{array}{l}\text { Documentary } \\
\text { analysis }\end{array}$ & & $\begin{array}{l}\text { media reports, } \\
\text { publicity } \\
\text { materials, } \\
\text { contest rules }\end{array}$ & $\begin{array}{l}\text { (September } \\
\text { 2013-July } \\
\text { 2014) }\end{array}$ & $\begin{array}{l}\text { Reading, studying and selection of data } \\
\text { documents }\end{array}$ \\
\hline $\begin{array}{l}\text { Observation } \\
\text { (direct } \\
\text { observation of } \\
\text { researchers) }\end{array}$ & $\begin{array}{l}\text { Community } \\
\text { members }\end{array}$ & $\begin{array}{l}\text { post, blogs, } \\
\text { interaction }\end{array}$ & $\begin{array}{l}\text { (September } \\
\text { 2013-July } \\
\text { 2014) }\end{array}$ & $\begin{array}{l}\text { Classification, analysis and } \\
\text { interpretation of data according to the } \\
4 \text { categories defined in the research } \\
\text { construct: } \\
\text { 1. actors' roles } \\
2 . \quad \text { activities developed } \\
3 \text { resources integrated } \\
4 \text {. co-created and captured value }\end{array}$ \\
\hline $\begin{array}{l}\text { Online survey } \\
\text { (questionnaire } \\
\text { including both } \\
\text { open and closed } \\
\text { questions) }\end{array}$ & $\begin{array}{l}\text { Designers, } \\
\text { brand } \\
\text { lovers ( } 150 \\
\text { respondents) }\end{array}$ & $\begin{array}{l}\text { role and } \\
\text { degree of } \\
\text { involvement } \\
\text { within the } \\
\text { community } \\
\text { achieved } \\
\text { benefits }\end{array}$ & $\begin{array}{l}\text { (February - } \\
\text { July 2014) }\end{array}$ & $\begin{array}{l}\text { Classification, analysis and } \\
\text { interpretation of } \\
\text { - data about the role and the } \\
\text { engagement according to the } 3 \\
\text { categories of research construct: } \\
\text { 1. actors' role } \\
\text { 2. activities developed } \\
\text { 3. resources integrated } \\
\text { data about achieved benefit } \\
\text { according the category } 4 \text { of } \\
\text { research construct } \\
\text { 4. co-created and captured value }\end{array}$ \\
\hline $\begin{array}{l}\text { Direct } \\
\text { interview } \\
\text { In-depth } \\
\text { problem } \\
\text { centered } \\
\text { interviews } \\
\text { according to a } \\
\text { narrative, text- } \\
\text { based research } \\
\text { design. }\end{array}$ & $\begin{array}{l}\text { Business } \\
\text { Partner } \\
\text { Formabilio } \\
\text { CEO }\end{array}$ & $\begin{array}{l}\text { content and } \\
\text { evolution } \\
\text { of the } \\
\text { relationship } \\
\text { respondents } \\
\text { engagement in } \\
\text { the Formabilio } \\
\text { Network }\end{array}$ & $\begin{array}{l}\text { (May } 2014 \text { - } \\
\text { July 2014) }\end{array}$ & $\begin{array}{l}\text { Codification, analysis and } \\
\text { interpretation of : } \\
\text { - } \quad \text { information about the interaction } \\
\text { between and among partners } \\
\text { according the } 4 \text { categories defined } \\
\text { in the research construct } \\
\text { information about the content of } \\
\text { the relationship in } 4 \text { categories } \\
\text { (Russo Spena and Mele, 2012): } \\
\text { co-design } \\
\text { 2. co-evaluation } \\
\text { 3. co-development } \\
\text { 4. co-learning } \\
\text { information about the evolution } \\
\text { of the relationship in } 2 \text { categories } \\
\text { 1. dyadic relationship (Anderson } \\
\text { et al. 1994) } \\
\text { 2. multi-actor relationship(Vargo } \\
\text { and Lusch, 2011). }\end{array}$ \\
\hline
\end{tabular}

Source: our elaboration 
Formabilio is an Italian start up that produces furniture, lighting and home accessories designed by creative minds from all over the world in a participatory and eco-friendly way. It is a community of talented designers who propose innovative solutions with style, comfort and according to sustainability standards. Formabilio "is a contest provider" as the co-founder says, "it organizes call for ideas to gather through digital platform the most original and innovative ideas from the creative community crowd". Ideas are chosen by a community of design lovers, manufactured by small enterprises of the made in Italy and sold online on the web-platform Formabilio.com.

Within the Formabilio platform, each designer can manage a personal page - "our designers" - where he/she introduces his/her passions and experiences and the creative solution proposed to the community.

The architecture of the digital platform allows Formabilio to fit the users' needs with the designers' ideas and the know-how of the business partners. Indeed, all the submitted ideas are evaluated, commented and voted by designers, and potential customers. The community judgment drawn from a formula that bonds the number of votes, the average of the opinions (e.g. I don't like it, do it better; good, I like it and great) and the reputation of voters. The best idea in terms of innovation, sustainability and appeal is selected and submitted to the evaluation of a jury of experts, including Formabilio's staff, business partners, and experts. Winning ideas are produced by the small craftsmanship companies, partners of Formabilio, in full compliance with the know-how and the high quality of the made in Italy tradition.

All realized products are marketed online through the platform. The Formabilio business model is based on online sales. It grants to the winning designers a fee of $7 \%$ on all sold products and to the community a $10 \%$ discount on the products purchased if they have voted and chosen a winning project. The company's goal is to value the skills of all the players involved. The activities counter lists each action carried out by the community members and grades their involvement in the project by building their reputation.

Within four months from its launch, more than 40,000 people have registered and have joined the Formabilio's community. Among them, 700 designers submitted more than 1,100 projects for the first four contests. Up to now, 96,549 users joined the platform and 2,415 young designers have been involved in 32 ideas contests by submitting a total of 5,590 proposals. The community has voted 26,800 times and commented more than 52,000 times. More than 80 ideas to produce have been selected and 44 have been realised by the Partners involved in the project and are now available at the online shop.

\section{Findings}

In this section we report the results of the study we carried out according to the construct of research outlined above. 


\section{sinergie} Vol. 33, N. 98, 2015

\subsection{Actors and roles}

The main actors involved within the network are designers and business partners. Both of them act as primary resource integrators, as they provide input for the design and the further realization of new products through new materials and new applications, as demonstrated by the following quotes.

"G: Very good! I like your idea. Probably you can use a part of it for the lamp backing. Anyway my vote is 5, the maximum. S: I think you're right. I can regain more space. Thank you so much for your suggestion".

Giancarlo and Silvia, Formabilio designers.

"The knowledge exchanged within the community allows the optimization of products and solutions. I remember a conversation of a designer who provided suggestions to better fit an idea. The proposal has been changed according to the suggestions and has been evaluated successfully in the following contest".

Denis, CEO Euroline- Partner.

As quotes reveal, Formabilio is the hub of the network. The company enhances the integration of resources among all players involved in the project. It plays as the intermediary of the innovation process, establishing connections and relationships among the actors of the community. Thanks to Formabilio, actors are networked with each other even on issues which are also beyond the specific context. Furthermore, it supports the co-design, co-evaluation, co-production and co-learning within the community by channeling and allowing the matching of the actors' skills and knowledge to improve their effectiveness as resource integrators and to set up a new way of creating value.

"Formabilio goes between us and the designers to solve problems or to redefine some details of the product. ...bridges the gap between the actors of the community as it interprets the need of both supplier and designers. Furthermore, it is possible to interact personally with the designers during the events organized by Formabilio"

Denis, CEO Euroline - Partner.

Potential customers or made in Italy-furnishing lovers are a typology of actors; who differently from the previous ones, don't affect decisively the creative process but their contribution is valuable as they provide comments, remarks and opinions on the product, materials, etc. Such community insights are considered to select the most interesting ideas and to test the product before its launch on the market.

"I like it, interesting project. I'll vote it".

Andrea, Formabilio community member.

"Good job! Your projects are always original and interesting, but please, could you replace the green color with another one? It is too common and used".

Davide, Formabilio community member. 
"Formabilio gives us the opportunity of direct feedback from customers about products. Traditionally, suppliers of components, like my company that has mainly B2B relationships, has not any direct relationship with customers...now, due to the engagement in the community of Formabilio, we are more aware and interested in the customers' opinion. It marks our route and pushes us to interact more with designers and other suppliers within the supply chain - to refine products according to the customers' preference".

Denis, CEO Euroline - Partner.

\subsection{Resources}

All actors are resource integrators. They integrate their own resources with the ones made available from the community in different ways and intensity depending on the typology of role, skills, and of the relationship they engage. Specifically, they integrate human knowledge, skills, time, effort - as well as non-human resources relating to the technical infrastructure to create new and sustainable solutions.

Data analysis and quotes from the questionnaire and the direct interviews highlighted that the main resources that actors integrate within the community of Formabilio are creativity, knowledge, technical and artistic competences, as well as, the made in Italy culture. Such resources can be meant as a sort of shared values between partners. Actors are continually encouraged to act upon, recombine and improve existing resources, as well as, to create new ones. This mechanism is well-recognised within the community as the suitable way to shift ideas into new and original products.

"Formabilio allow us to offer to the creativity of designers all our skills, competences and all our 60 years of experience and tradition, to further their opportunities and ours".

Katia, Manager Ivo Fontana Mobili - Partner.

"The traditional mistrust within the supply chain has been replaced by the culture of collaboration. I have the opportunity to improve my work by learning working techniques that belong to interrelated business (Supplier Company) and that till a year ago I perceived as something far away from my work".

Denis, CEO Euroline- Partner.

Technology (especially when referred to the technical infrastructure of the digital platform) is a core factor for the process of resources integration and for the development of collaborative approach to the value creation. Formabilio.com is a user-friendly interface designed to ensure access, transparency (e.g. idea contest rules, project evaluation rules, etc.), visibility of the community members (e.g. recognition by both peers and companies), sharing of information and opinion, and to provide the opportunities to collaborate. It is fundamental for stimulating and driving the participants' activities. Social software - Twitter, Facebook, Vimeo, YouTube, etc. complement the technical infrastructure provided by Formabilio, but, differently from the blog and the space within Formabilio.com, they are used 
sinergie Vol. 33, N. 98, 2015

mainly by the companies to communicate the launch of new contests, events and news instead of sharing and commenting ideas. Social networks are just communication tools for Formabilio.

"Our records reveal that community members prefer to interact and exchange opinions and ideas within the digital platform Formabilio. com instead of on the Facebook fan page. This trend is confirmed by the request of the community for a forum to freely interact".

Maria Grazia, Formabilio Co-founder.

\subsection{Activities}

Activities can be simple activities, such as, compliance with community (liking and voting), collecting information (discussions observation), buying products, and/or complex activities, such as, suggesting new ideas, commenting ideas (provide suggestion to improve ideas), evaluating the technical feasibility of product solutions, producing wining products and co-learning. Members can be involved in one or more tasks according to their role within the community.

"Formabilio is a sharing community; it is a creative lab that puts ideas in practice".

Luca, Formabilio designer.

"Formabilio is a showcase for the GOOD DESIGN. It pays attention to the experimentation, encourages creativity and fosters the sharing and comparison among experts". Chiara, Formabilio designer.

"I discovered Formabilio quite by accident. I saw the spirit of the competition, the quality of products and especially the opportunity to share, discuss and refine my skills, so I couldn't resist getting involved". Livia, Formabilio designer.

More complex activities require the actors' cognitive effort; they relate to product purchase and idea co-evaluation, which is based on community votes and on the analysis of an idea's technical feasibility by experts, manufacturing companies and the Formabilio founders. Other activities requiring high actor engagement relate to idea co-design, which is based first on the creative contribution of the designer (new idea submission) and in the second stage on the collective actions of the community members, including small craftsmanship and high specialized companies (business partners) that provide comments and suggestions to improve and better fit ideas to market needs. Comments and suggestions for idea improvement are allowed by the direct interaction among the business partners and between them and designers. These activities foster co-design, co-development and co-learning the creation and sharing of new knowledge and of new product solutions.

Such activities foster and nourish the practice of innovation by enhancing the logic of collaboration and value co-creation for all actors involved in the project. 
The company's goal is to produce and share value with all players involved in the project. We identified different types of value: economic and financial, social, emotional and epistemic. For designers value is related, first of all, to the opportunity to increase their professional competences as well as to obtain trust and social recognition as a "professional designer" by peers, firms and potential customers (e.g. each Formabilio product is marked with the designer and manufacturer names). Moreover, they also extract economic value from the collaboration as they gain monetary reward for each sold product they have designed (a fee of $7 \%$ on all sold products).

"I believe Formabilio is a good chance to keep in touch with people who want to share ideas and knowledge. It allows the stand out of young professional designers and their cooperation with potential customers and firms".

Maddalena, Formabilio designer.

“...my favorite Formabilio product is 'Nestore', when I saw it on Formabilio, it made me smile. There is nothing more appropriate than a sofa to represent comfort, free time, a shelter against stress. 'Nestore' combines together a relax area for humans and for pets. I find this idea really original. The petroleum green version is the one I like the best, by the way".

Fabio, Area Pavimenti - Partner.

'The Partners' are small-size, craftsmanship and high specialised Italian firms that are very sensitive to environmental, sustainability and made in Italy issues. For them value depends firstly on business and network opportunities. Joining the Formabilio community allowed small companies to access wider network and to get in touch with other companies and partners. Such type of value leads to - or is a precondition for- economic and financial value. Moreover, value is related to the evolution of the actors' relationship, that shifts from a dyadic to a multi-actor level by allowing the exchange of different knowledge, competences and abilities to cope with the technological and market challenges.

"Formabilio is the future. It gives us the opportunity to work with designers who have new ideas and, above all, the opportunity to enter in a global market".

Paolo, Live In - Partner.

"We have no doubt that the furniture industry is suffering from recession and it needs change and revolution. A part of this change is shown in the very innovative development and sale system applied by Formabilio. We grew up in terms of relationships with other suppliers and designers. We have information about materials and manpower costs that before were not easily accessible; furthermore, the reference system enacted by Formabilio allowed us to be engaged in other projects outside the community".

Denis, CEO Euroline- Partner. 
Sinergie Vol. 33, N. 98, 2015

Value for members of community is epistemic, social and emotional too, as all enthusiastic people who contribute by commenting and participating increase their own knowledge (about products, processes, designers, firms, materials, events....) and also find entertainment as they are design lovers and innovation sensitive. The first type of value for customers depends surely on the collaborative nature of the process: they are partners in the process of selection of the idea: they feel very deeply this participation and it is a great self-esteem benefit and gratification. The value for the customers is complex and is related to the awareness of a solution which matches design, price, quality and sustainability (work processes, materials, employees respect, and innovative culture). Of course customers can wish for different types of value depending on their own engagement, system of values, role and expectations.

\section{Discussion}

Companies are increasingly seeking to foster collaboration, as it is a key factor for the organisational success, performance improvement and survival in the competitive arena (Trott and Hartmann, 2009; Chesbrough, 2003; Chesbrough and Crowther, 2006). Recently, manufacturing companies, operating in the mature and traditional industry, are trying to enrich the potentialities of traditional and strengthened methods through the use of interactive technologies to source, select and test new ideas (e.g. ideas contest). Formabilio uses the digital environment to favor the sharing of resources and the cooperation between all the actors of the network. This type of open behavior combines the competitive feature of the challenge with the opportunity of interaction and collaboration enhanced by the digital platform (Hutter et al., 2011).

Drawing from the idea that WBTs enable innovative business models (Osterwalder, 2004), our study stresses the role of interactive technologies to boost an innovative business model based on a collaborative relationships.

This practice has effects the working activities and processes of all the actors involved in the project. It extends their business boundaries and prioritizes the interaction and the sharing of information, knowledge, competences, etc. with new actors in a changeable relationship system. Indeed, as quotes cited above have highlighted, suppliers of component products - who have traditionally focused on a narrow business approach - cooperate with other actors (e.g. Formabilio, designers, other suppliers, furniture experts and customers) from the design to the product prototyping stage.

Multi-actors' relationship makes this case unique and more complex in comparison to other examples (e.g. Nel Mulino che Vorrei, Nutella, Dell etc.) in which companies focus on dyadic relationships (e.g. company and consumers, company and experts, company and fans). Indeed, Formabilio encompasses the point of view of many participants who are actively engaged in different activities (co-design, co-evaluation, co-production etc.) within the entire business ecosystem (figure 2). 
Formabilio (the company) ensures preconditions for triggering and developing resource integration (Colurcio et al., 2014) that is the matching between skills and knowledge of different actors. Formabilio empowers the actors: due to their engagement in the relationship, they become effective resource integrators and thus value co-creators and value capturers (Vargo, 2008; Vargo and Lusch, 2008).

Fig. 2: The Formabilio Business Model

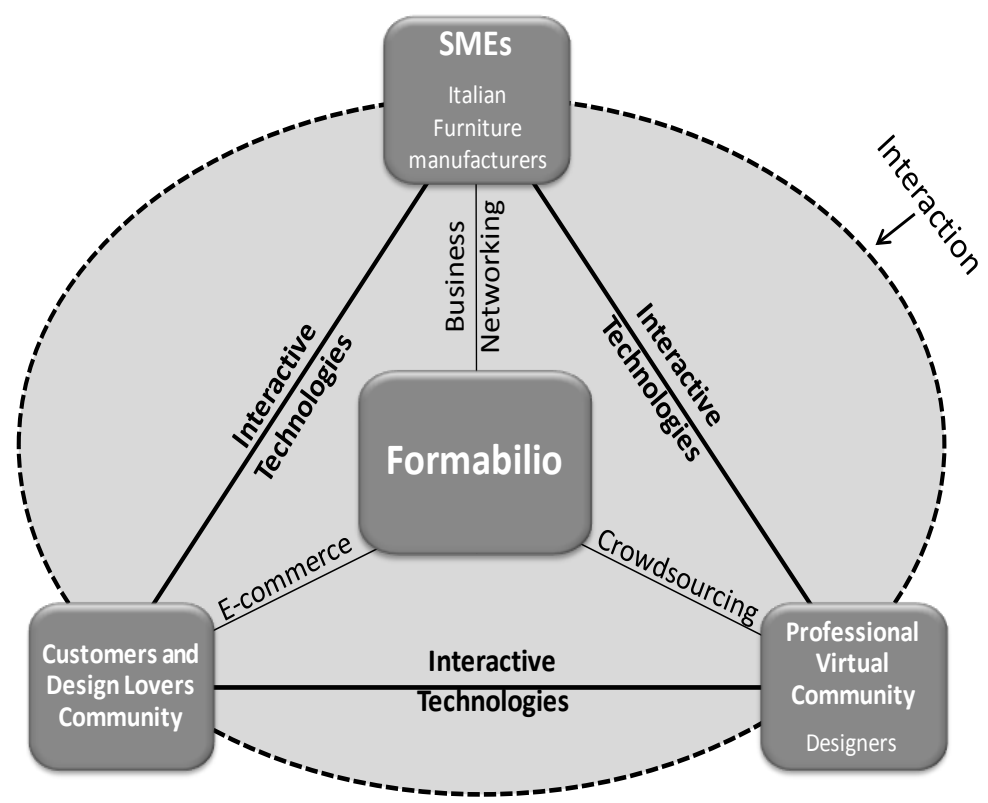

Source: Our elaboration

Value emerges in and through the community and is enabled by WBTs, through the active doing and the resource integration process. WBTs enable diverse types of value - economic and financial, social, emotional and epistemic - to fit the different actors' expectations. These depend on the actors' roles, and thus on the nature of service exchange and on the type of the resource integrated.

As stressed above, interactive technologies are operant resources (Caridà et al., 2014; Akaka and Vargo, 2014) which enable the development of the collaborative based business model and ensure its progressive adaptation to the changing circumstances and contexts (Osterwalder et al., 2005).

Hence, the collaborative-based business model we argued in the present study is not a static concept as it can may vary over the time (Osterwalder $e t$ al., 2005; Zott et al., 2011), depending mainly on the networking system that it creates and is created by the business model according to a dynamic and interactive view which privileges the value co-creation purpose. 


\section{sinergie}

Vol. 33, N. 98, 2015

\section{Main implications}

The study emphasizes a broad view of business model which comprises and emphasizes the value (co) - creation process. Indeed, it stresses the role of the entire network in creating value (e.g. economical and financial, social, emotional and epistemic) and goes beyond the mere engagement of customers (Brodie et al., 2011; McGrath and MacMillan, 2000) as it relates to the engagement of all actors (Chandler and Vargo, 2011) and to the interaction and relationship between them (A2A).

This study contributes from both theoretical and managerial perspectives. It supports the existing studies pertaining to business model and provides an integrated perspective of topics that have been different and separately deepened so far.

According to Berglund and Sandström (2013), we have framed the business model as a set of components that transcend the boundaries of the firm to become a new unit of analysis (Stähler, 2002; Zott et al., 2011). The business model is a system-level concept that is centered on activities and focused on value creation and on value capture (Zott et al., 2011). On the basis of the shared issues between all the three research streams of literature - technology, network, innovation (Berglund and Sandström, 2013; Zott et al., 2011), we have identified the pivotal factors for the designing of value co-creation oriented business model i) resources; ii) actors; iii) value, and iv) mechanisms (interaction/sharing) and rules for the performance (resource integration process) of the model. Resources (operant) are the main source of the competitive advantage and all the actors of the network are different in quality and quantity. Afterward, the competitive advantage depends on all the actors of the network and it is not a mere output of the firm activities: it is the outcome of a social and collective process, the value co-creation process (Vargo and Lusch, 2008). The actor to actor interaction (A2A) converts value creation into a value co-creation process in which the value emerges only from the integration (Caridà et al., 2014; Vargo and Lusch, 2008) and the transformation of resources: all the actors integrate resources and cooperate to gain a competitive advantage for the entire system.

The study addresses the need of academia to design through the business model a supportive environment for resource integration and value co-creation (Frow et al., 2015; Storbacka et al., 2012). It calls for a new and more strategic role of the business model to replace episodic activities and use a structured, codified and recursive mechanism to create value for all the actors engaged. It emphasizes that the cooperation, interaction and integration of resources are not simple techniques or tools to put on. The study can support practitioners to better design and manage a business model based on the resource-integration mechanism and value co-creation, which according to many authors are fundamental sources of competitive advantage. Moreover, it offers some insights on how to exploit interactive technologies to mobilize and enhance the best combination of actors' resources to create a collaborative and networked environment in a traditional and not open business context such as the Italian manufacturing. 


\section{Limits and further research}

In summary, on the one hand, our study provides fresh insights and integrates the elements that are crucial for the design of a business model in the global context in which some ethical and social issues are becoming more and more relevant. On the other hand, our study also reveals relevant limitations.

It is one-case focused taking an exploratory approach. The analysis indeed is descriptive and does not provide a prescriptive framework to design business models for managing value creation opportunities. However, it opens up interesting research opportunities on the role of business model in explaining how value is co-created, and on the need to frame the business model design as a fundamental phase to replace episodic activities and be innovative using a structured, codified and recursive mechanism to create value for all the actors engaged. Furthermore, it emphasises the need to create a new business approach, based on networked value creation and to renovate existing and traditional businesses context. Finally, additional studies should focus on different cases and gain a better understanding of the role of IT in diverse sectors and contexts.

\section{References}

AFUAH A., TUCCI C. (2003), Internet Business Models and Strategies, McGraw Hill, Boston.

AKAKA M.A., VARGO S.L. (2014), "Technology as an operant resource in service (eco) systems", Information Systems and e-Business Management, vol. 12, $\mathrm{n}$. 3, pp. 367-384.

AMIT R., ZOTT C. (2001), "Value creation in e-business", Strategic Management Journal, vol. 22, n. 6-7, pp. 493-520.

ANDERSON J.C., HÅKANSSON H., JOHANSON J. (1994), "Dyadic business relationships within a business network context", The Journal of Marketing, vol. 58, n. 4, pp. 1-15.

BALLANTYNE D., VAREY R.J. (2006), "Creating value-in-use through marketing interaction: the exchange logic of relating, communicating and knowing", Marketing theory, vol. 6, n. 3, pp. 335-348.

BERGLUND H., SANDSTRÖM C. (2013), "Business model innovation from an open systems perspective: structural challenges and managerial solutions", International Journal of Product Development, vol. 18, n. 3, pp. 274-285.

BOURDEAU L., CHEBAT J.C., COUTURIER C. (2002), "Internet consumer value of university students: E-mail-vs.-Web users", Journal of Retailing and Consumer Services, vol. 9, n. 2, pp. 61-69.

BRODIE R.J., HOLLEBEEK L.D., JURIĆ B., ILIĆ A. (2011), “Customer Engagement Conceptual Domain, Fundamental Propositions, and Implications for Research", Journal of Service Research, vol. 14, n. 3, pp. 252-271.

BURR V. (2003), Social constructionism, Routledge, London.

CAMARINHA-MATOS L.M. (2009), "Collaborative networked organizations: Status and trends in manufacturing", Annual Reviews in Control, vol. 33, n. 2, pp. 199-208. 
sinergie Vol. 33, N. 98, 2015

CAMMOCK P., NILAKANT V., DAKIN S. (1995), "Developing a lay model of managerial effectiveness: A social constructionist perspective", Journal of Management Studies, vol. 32, n. 4, pp. 443-474.

CARIDÀ A., COLURCIO M. (2013), "Viral Marketing Communication: Just Sales or More?", Business Systems Review, vol. 2, n. 1, pp. 99-110.

CARIDÀ A., COLURCIO M., MELIA M. (2014), "Rethinking and improving the healthcare service through interactive web technologies", in Baglieri E., Karmarkar U., Managing Consumer Services: Factory or Theater?, Springer International Publishing (ed.) Cham (ZG), Switzerland.

CHANDLER J., VARGO S.L. (2011), "Contextualization: Network intersections, value-in-context, and the co-creation of markets", Marketing Theory, vol. 11, n. 1 , pp. 35-49.

CHESBROUGH H.W. (2003), Open innovation: The new imperative for creating and profiting from technology, Harvard Business School Press, Boston.

CHESBROUGH H., CROWTHER A.K. (2006), "Beyond high tech: early adopters of open innovation in other industries", RङD Management, vol. 36, n. 3, pp. 229-236.

CHESBROUGH H., ROSENBLOOM R.S. (2002), The Role of the Business Model in capturing value from Innovation: Evidence from XEROX Corporation's Technology Spinoff Companies, Harvard Business School Press, Boston.

CHIARVESIO M., DI MARIA E., MICELLI, S. (2004), "From local networks of SMEs to virtual districts?: Evidence from recent trends in Italy", Research Policy, vol. 33, n. 10, pp. 1509-1528.

COLURCIO M. (2009), "Asymmetric business relationships and interaction capabilities: an exploratory study", Quaderni di Sinergie, n. 16, pp. 109128.

COLURCIO M., EDVARDSSON B., CARIDÀ A. (2014), "Resource integration in innovation processes: a literature review", Edited by Ahram T., Karwowski W., Marek T., Proceedings of the 5th International Conference on Applied Human Factors and Ergonomics AHFE 2014, Kraków, Poland 19-23 July.

COLURCIO M., WOLF P., KOCHER P.Y., RUSSO SPENA T. (2012), "Asymmetric relationships in networked food innovation processes", British Food Journal, vol. 114, n. 5, pp 702-727.

CRESWELL J.W. (1998), Qualitative inquiry and research design: Choosing among five designs, Sage, Thousand Oaks, CA.

DEIGHTON J., GRAYSON K. (1995), "Marketing and seduction: Building exchange relationships by managing social consensus", Journal of Consumer Research, vol. 21, n. 4, pp 660-676.

EDVARDSSON B., TRONVOLL B., GRUBER T. (2011), "Expanding understanding of service exchange and value co-creation: a social construction approach", Journal of the Academy of Marketing Science, vol. 39, n. 2, pp 327-339.

FINN M., WALTON M., ELLIOTT-WHITE M. (2000), Tourism and leisure research methods: Data collection, analysis, and interpretation, Pearson education Ltd, Harlow, UK.

FRANKFORT-NACHMIAS C., NACHMIAS D. (1996), "Index construction and scaling methods", in Frankfort-Nachmias C., Nachmias D., Research methods in the social sciences, St Martin's Press, London. 
FROW P., NENONEN S., PAYNE A., STORBACKA K. (2015), "Managing co- Angela Caridà creation design: a strategic approach to innovation", British Journal of Monia Melia Management, DOI: 10.1111/1467-8551.12087

GERGEN K.J. (1985), “The social constructionist movement in modern psychology”, American Psychologist, vol. 40, n. 3, pp. 266-75.

GOSS D. (1991), Small Business and Society, Routledge, London.

HAMEL G. (2000), Leading the revolution, Harvard Business School Press, Boston.

HAMMERSLEY M., ATKINSON P. (1995), Insider accounts: Listening and asking questions. Ethnography: Principles in practice, Routledge, London.

HUTTER K., HAUTZ J., FÜLLER J., MUELLER J., MATZLER K. (2011), "Communitition: The Tension between Competition and Collaboration in Community-Based Design Contests", Creativity and Innovation Management, vol. 20, n. 1, pp. 3-21.

JOHNSEN R., FORD D. (2008), "Exploring the concept of asymmetry: a typology for analyzing customer-supplier relationships", Industrial Marketing Management, vol. 37, n. 4, pp. 471-483.

LEE S., PARK G., YOON B., PARK J. (2010), "Open innovation in SMEs-An intermediated network model”, Research policy, vol. 39, n. 2, pp. 290-300.

LINCOLN Y.S., GUBA E.G. (1985), Naturalistic inquiry, Sage Publications, Beverly Hills, CA.

LUCKMANN T., BERGER P.L. (1991), The social construction of reality: a treatise in the sociology of knowledge, Anchor Books, New York.

McALEXANDER J.H., SCHOUTEN J.W., KOENIG H.F. (2002), "Building brand community", Journal of Marketing, vol. 66, n. 1, pp. 38-54.

McCOLL-KENNEDY J.R., VARGO S.L., DAGGER T.S., SWEENEY J.C., VAN KASTEREN Y. (2012), "Health care customer value co-creation practice styles", Journal of Service Research, vol. 15, n. 4, pp. 370-389.

McGRATH R., MACMILlAN I., (2000), Discovery Driven Planning, Harvard Business Press, Boston.

MELE C., RUSSO SPENA T., COLURCIO M. (2010), “Co-creating value innovation through resource integration", International Journal of Quality and Service Sciences, vol. 2, n. 1, pp. 60-78.

MORRIS M., SCHINDEHUTTE M., ALLEN J. (2005), “The entrepreneur's business model: toward a unified perspective", Journal of Business Research, vol. 58, n. 6, pp. 726-735.

MYERS J. (2006), "Future value systems: Next generation economic growth engines \& manufacturing”, in Choi B.W., Nagy D. (Eds.), IMS vision forum IMS International, Seoul, Korea.

OSTERWALDER A., PIGNEUR Y., TUCCI C.L. (2005), "Clarifying business models: Origins, present, and future of the concept", Communications of the association for Information Systems, vol. 16, n. 1, pp. 1-40.

OSTERWALDER, A. (2004), The business model ontology: A proposition in a design science approach, Institut d'Informatique et Organisation, University of Lausanne, Ecole des Hautes Etudes Commerciales HEC, 173, Lausanne, Switzerland.

PRATTEN C. (1991), The Competitiveness of Small Firms, Cambridge University Press, Cambridge 
sinergie Vol. 33, N. 98, 2015

PURA M. (2005), "Linking perceived value and loyalty in location-based mobile services", Managing Service Quality: An International Journal, vol. 15, n. 6, pp. 509-538.

RAMPERSAD G., QUESTER P., TROSHANI I. (2010), "Managing innovation networks: Exploratory evidence from ICT, biotechnology and nanotechnology networks", Industrial Marketing Management, vol. 39, n. 5, pp. 793-805.

ROTHWELL R., DODGSON M. (1992), "European technology policy evolution: convergence towards SMEs and regional technology transfer", Technovation, vol. 12, n. 4, pp. 223-238.

RUSSO SPENA T., COLURCIO, M. (2010). "A cognitive-relational view of innovation in the agri-food industry: the fresh-cut business", International Journal of Innovation Management, vol. 14, n. 2, pp. 307-329.

RUSSO SPENA T., MELE C. (2012), "Five Co-s" in innovating: a practice-based view", Journal of Service Management, vol. 23, n. 4, pp. 527-553.

SAWHNEY M., VERONA G., PRANDELLI E. (2005), "Collaborating to create: The Internet as a platform for customer engagement in product innovation", Journal of interactive marketing, vol. 19, n. 4, pp. 4-17.

SCHAU H.J., MUÑIZ JR. A.M., ARNOULD E.J. (2009), "How brand community practices create value”, Journal of Marketing, vol. 73, n. 5, pp. 30-51.

SHETH J.N., NEWMAN B.I., GROSS B.L. (1991), "Why we buy what we buy: a theory of consumption values", Journal of Business Research, vol. 22, n. 2, pp. 159-170.

SICILIA M., PALAZÓN, M. (2008), "Brand communities on the internet: A case study of Coca-Cola's Spanish virtual community", Corporate Communications: An International Journal, vol. 13, n. 3, pp. 255-270.

STÄHLER P. (2002), Business Models as an Unit of Analysis for Strategizing, International Workshop on Business Models, Lausanne, Switzerland.

STEWART D.W., ZHAO Q. (2000), "Internet marketing, business models, and public policy", Journal of Public Policy and Marketing, vol. 19, n. 2, pp. 287-296.

STORBACKA K., FROW P., NENONEN S., PAYNE A. (2012), "Designing Business Models for Value Co-Creation”, in Vargo S., Lusch, R., Special Issue - Toward a Better Understanding of the Role of Value in Markets and Marketing, Review of Marketing Research, vol. 9, pp. 51-78.

SWEENEY J.C., SOUTAR G.N. (2001), "Consumer Perceived Value: The Development of a Multiple Item Scale”, Journal of Retailing, vol. 77, n. 2, pp. 203-220.

TEECE D.J. (2010), "Business models, business strategy, and innovation”, Long Range Planning, vol. 43, n. 2, pp. 172-194.

TIMMERS P. (1998), "Business Models for Electronic Markets", Journal on Electronic Markets, vol. 8, n. 2, pp. 3-8.

TROTT P., HARTMANN D. (2009), "Why 'open innovation' is old wine in new bottles", International Journal of Innovation Management, vol. 13, n. 4, pp. 715-736.

ULAGA W., EGGERT A. (2005), "Relationship value in business markets: the construct and its dimensions", Journal of Business-to-business Marketing, vol. 12, n. 1, pp. 73-99. 
VARGO S.L., LUSCH R.F. (2011), "It's all B2B... and beyond: Toward a systems perspective of the market", Industrial Marketing Management, vol. 40, n. 2, pp. 181-187.

Angela Caridà

Designing a collaborative

business model for SMEs

VARGO S.L. (2008), "Customer integration and value creation Paradigmatic Traps and Perspectives", Journal of service research, vol. 11, n. 2, pp. 211-215.

VARGO S.L., LUSCH R.F. (2008), "Service-dominant logic: continuing the evolution", Journal of the Academy of marketing Science, vol. 36, n. 1, pp. 1-10.

VON HIPPEL E. (2005), Democratizing innovation, MIT Press, Cambridge, MA.

WITZEL A. (2000), “The problem-centered interview”, Qualitative Social Research, vol. 1, n. 1. Retrieved from: http://nbnresolving.de/urn:nbn:de:0114fqs0001228 (Accessed: 14th June, 2014)

ZOTT C., AMIT R., MASSA L. (2011), “The business model: recent developments and future research", Journal of Management, vol. 37, n. 4, pp. 1019-1042.

\title{
Website
}

http://www.formabilio.com

\section{Academic or professional position and contacts}

\author{
Angela Caridà \\ Post doc Researcher of Management \\ University of Magna Græcia di Catanzaro - Italy \\ e-mail: angela.carida@unicz.it
}

\section{Maria Colurcio}

Associate Professor of Management

University of Magna Græcia di Catanzaro - Italy

e-mail:mariacolurcio@unicz.it

\section{Monia Melia}

Post doc Researcher of Management

University of Magna Græcia di Catanzaro - Italy

e-mail: monia.melia@unicz.it 